\title{
Maden ve Tünelcilik Sektöründe Kullanılan Sıcak Haddelenmiş TH34 Profilin Bükme Prosesine İliş̧kin Simülasyon Destekli Tasarımı, Prototip Üretimi ve Tahribatsız Muayene Yöntemi ile Analizleri
}

\author{
Aytaç BAŞSÜLLÜ*1, Hülya DURMUŞ² \\ ${ }^{1}$ Kocaer Haddecilik San. Tic. ve A.Ş., İzmir \\ ${ }^{2}$ Manisa Celal Bayar Üniversitesi, Mühendislik Fakültesi, Metalurji ve Malzeme Mühendisliği \\ Bölümü, Manisa
}

Geliş tarihi: 15.07 .2018

Kabul tarihi: 27.03.2019

$\ddot{\mathbf{O} z}$

Son yıllarda ülkemizde yaşanan maden kazaları sebebiyle birçok can kaybı yaşanmıştır. Bundan dolayı madencilik ve tünel inşa sektöründe yeni araştırmalar ortaya çıkmıştır. Yeni gelişmelerle tünel kısa zamanda, düşük maliyet ve yüksek kalitede tamamlayarak projelerinde beklenen hassasiyeti güvence altına almak mümkündür. Geçmişten günümüze kadar tahkimat malzemeleri maden ve tünelcilik sektörünü etkilemiştir. Son zamanlarda madencilik ve tünelcilik sektöründe farklı amaçlar için kullanım alanlarına sahip malzemelerden biri çeliktir. Çelik, ahşaba göre daha yüksek dayanıma sahiptir, çeşitli mekanizmalara göre şekillendirilebilir ve bu mekanizmaların yükü altında bozulmadan kullanılabilir. Çelik tahkimat sistemlerde son zamanlarda kullanılan profil ise Toussaint-Heitzmann (TH)'dır. TH profili tahkimatların servis ömrünü büyük oranda etkileyen soğuk deformasyon proseslerinin kontrollü ve en verimli süreç tasarımları ile elde edilebilirliğini ortaya çıkarmıştır. Bu çalışmada, sıcak haddeleme yöntemi ile elde edilen S480W malzemesinden TH34 profiller için, madencilik ve tünelcilik sektöründe kullanımı amacıyla galeri kesitlerine göre profilin bükme ile şekil verme süreçleri, sonlu elemanlar yöntemi ile tasarlanmıştır. Elde edilen çıktılar ile birlikte prototip üretim gerçekleştirilmiştir. Referans alınan galeri ark ölçüsüne göre prototip üretimi gerçekleştirilen profilin büküm yüzeyleri tahribatsız muayene yöntemleri kullanılarak incelenmiş ve plastik deformasyon kaynaklı çatlak oluşuma rastlanılmamıştır. Elde edilen sonuçlara göre çelik tahkimatların soğuk plastik deformasyonuna (bükme) ait en verimli proses tasarımının gerçekleştirildiği belirlenmiştir.

Anahtar Kelimeler: Madencilik, Tahkimat, Bükme prosesi, Simülasyon, Tahribatsız muayene

*Sorumlu Yazar (Corresponding author): Aytaç BAȘSÜLLÜ, a.bassullu@kocaergroup.com 


\title{
Simulation Assisted Design, Prototype Production and Non-Destructive Testing Methods of Bending Process of Hot Rolled TH34 Profile Used in Mining and Tunneling Sector
}

\begin{abstract}
In recent years there have been many casualties due to mining accidents in our country and there have been searches and anticipations for new developments in mining and tunnel construction sector. With the emergence of new developments, it is possible to secure the expected precision of tunnel projects in a short time, at low cost and high quality. From past to present day, ground support materials have affected the orientation of the mining and tunneling sector. One of the materials that have recently been used for various purposes in the mining and tunneling sector is steel. Steel is higher in strength than wood and can be shaped according to various mechanisms and can be used undisturbed under a load of these mechanisms.

The profile recently used in steel support systems is Toussaint-Heitzmann (TH). The TH profile reveals that the cold deformation processes affecting the service life of the ground supports can be achieved with controlled and efficient process designs. In this study, S480W material TH34 profiles obtained by the hot rolling method are designed by using finite element method for bending and shaping processes according to gallery sections for use in mining and tunneling sector. Prototype production was carried out with the results obtained. According to the reference gallery arc gauge, the bending surfaces of the profile produced prototype were examined by using non-destructive inspection methods and crack formation due to plastic deformation was not found. According to the results obtained, it has been determined that the most efficient process design for cold plastic deformation (bending) of steel ground supports is carried out.
\end{abstract}

Keywords: Mining, Ground supports, Bending process, Simulation, Non-destructive inspection

\section{GÍRISS}

Maden ve tünelcilik sektörünün en önemli kısımlardan biri tahkimatlardır. Tahkimat, yeraltı işletmelerinde çeşitli nedenlerden açılan yeraltı boşluklarının, belirli bir süre emniyetli bir şekilde tutulması için kullanılan destek üniteleridir. Oldukça fazla çeşitlilik gösteren tahkimat işlemleri, teknolojinin gelişimi ve işletme maddi olanakları ile birlikte, basit ahşap malzemelerle yapılan tahkimatlardan, hidrolik sistem ile çalışan makinelere kadar değişiklik göstermektedir [1].

Son yüzyılda dünyada gerçekleşen hızlı gelişmeler, maden ve tünelcilik sektörünün ihtiyaçlarına bağlı olarak hızla geliştiği belirlenmiş ve günümüzde tünelcilik çalışmalarında ortaya çıkan yeni gelişmeler tünel projelerinin istenilen hassasiyette, güvenli olarak en kısa zamanda ve düşük maliyet ve yüksek kalite ile tamamlanmasını sağlamaktadır $[2,3]$. Tahkimat uygulamasındaki çeşitli eksiklikler nedeniyle, yeni malzeme kullanım ihtiyaçları artmıştır. Son zamanlarda farklı amaçlarla farklı kullanım alanlarına sahip malzeme çeliktir. Çelik esaslı malzemelerin şekillendirilmesinde en sik kullanılan plastik şekil verme metotlarından biri, haddelemedir. Haddeleme prosesi, soğuk ve sicak olmak üzere ikiye ayrılmaktadır $[4,5]$.

Sicak haddeleme prosesi, metal esasl1 malzemelerden çeşitli tasarımlara sahip profillerin elde edilmesi amacı ile kütük, slab ve bloom gibi hammaddelerin tav firınlarında östenitleme sıcaklığına kadar 1sitılarak merdanelerden geçirilmesi ile plastik deformasyona uğratılması, kontrollü soğutma ile tane oluşumunun tamamlanarak akabinde standartlarda belirtilen ölçü toleranslarına getirilmesi için doğrultma 
merdanelerinden geçirilmesini takip eden plastik şekil verme yöntemidir. Haddeleme ile üretilen ürünler, demiryolu, yapı sektörü, otomotiv, maden ve tünelcilik sektörü gibi farklı sektörlerde kullanılmaktadır. Sicak haddeleme yöntemiyle üretilen Toussaint-Heintzmann $(\mathrm{TH})$ profilleri'nin sahip olduğu özel kesit tasarımı nedeniyle dikey ve yatay eksenlerdeki mukavemet momentleri birbirine çok yakın olup ayrıca bu profiller, burkulma, eğilme, burulma gibi mekanik zorlamaların olduğu sistemlerde kullanılabilecek en iyi profillerdir [6].

Belirtilen özellikler sebebiyle maden ve tünelcilik sektöründeki faaliyetlerde tahkimat sistemlerinde kullanılan başlıca elemanlardır. Sıcak haddeleme yöntemiyle uzun profiller halinde üretilen bu profiller, galeri ve tünellerde bu halleri ile kullanılamamaktadır. Standartlarda yer alan galeri ve açıklıklarda olması gerekmektedir. Bu sebeple $\mathrm{TH}$ profillerinin kayar tahkimat, trapezoid gibi şekillerde montajlanabilmesi için soğuk deforme edilmeleri ya da bükme yöntemiyle şekillendirilmeleri gerekmektedir. Bükme işlemleri sırasında malzemelerde bir takım geri yaylanma meydana gelmekte olup, geri yaylanma davranışları kesit şekline, ölçülerine, büküm yarıçapına, hadde yönüne, malzemenin mekanik özelliklerine göre değişkenlik göstermektedir [7-10].

Bükme yöntemi, malzemelerin 1sitılarak ya da 1sıtılmadan ve talaş kaldırılmadan, belirli bir eksen etrafinda döndürülmesi ile şekillendirilmesi olarak tanımlanabilmektedir [11]. Son zamanlarda bükme ile şekillendirme yöntemlerinin gelişmesiyle, birçok sektörde bükme makineleri ihtiyaç haline gelmiştir. Günümüzde hidrolik sanayi, demir-çelik sektörü, denizcilik gibi birçok sektörde bükme makineleri kullanılmaktadır. Demir esaslı ve demir dışı malzemelerin üzerine bir kuvvet uygulanması ile bükme prosesleri gerçekleşmektedir. Malzeme üzerine uygulanan kuvvet ile malzeme bükmeye zorlandığında dış yüzeyde çeki, iç yüzeyde bası gerilmeleri oluşmaktadır. Böylece çeki gerilmelerinin bulunduğu yüzey uzayacak, bası gerilmelerinin bulunduğu yüzey ise kısalacaktır (Şekil 1) [12].

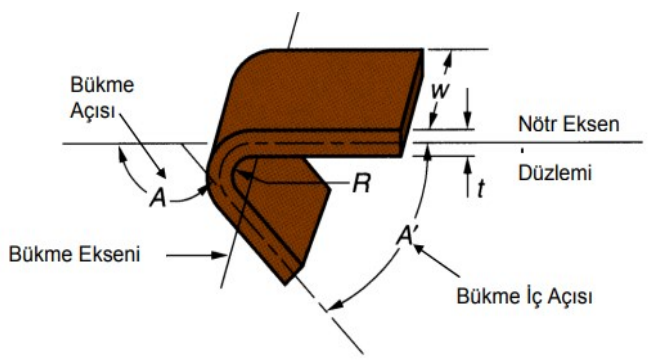

(a)

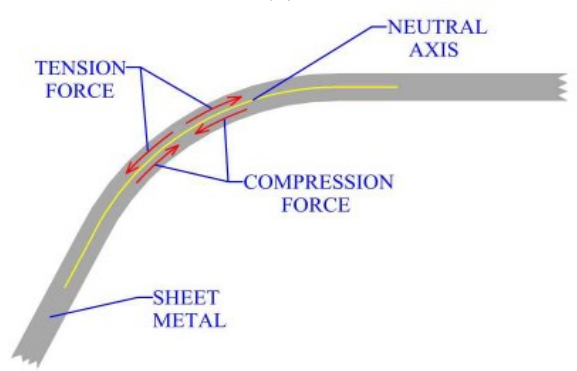

(b)

Şekil 1. (a) Bükme işlemlerinde kullanılan parametreler ve (b) Bükme işlemlerinde meydana gelen çeki ve bası gerilmeleri [12]

Bükme prosesi; bükme, kenar bükme, kıvırma bükme, katlama ve kenet bükme, oluklama bükme, kabartma bükme ve vals topları ile bükme olarak altı ana başlık altında sınıflandırılmaktadır (Şekil 2) [12].

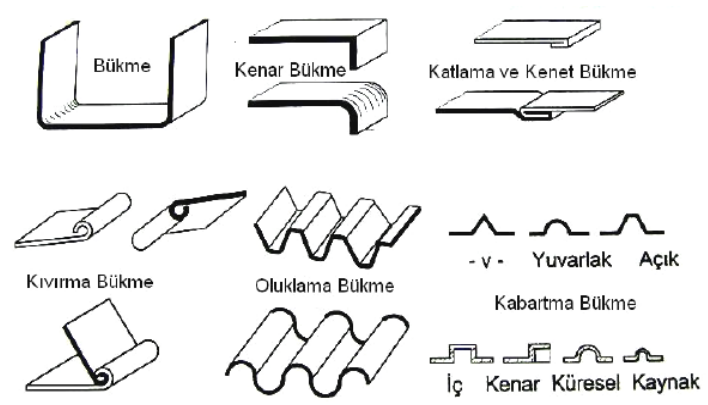

Şekil 2. Bükme proses çeşitleri ve örnekleri [12]

Şekil verme işlemlerinin akabinde yük boşaltımı sırasında metal levhanın şeklinin elastik olarak değişime uğraması sonucunda geri esneme meydana gelmektedir (Şekil 3). Bükme işlemleri 
Maden ve Tünelcilik Sektöründe Kullanılan Sicak Haddelenmiş TH34 Profilin Bükme Prosesine İlişkin Simülasyon Destekli Tasarımı, Prototip Üretimi ve Tahribatsız Muayene Yöntemi ile Analizleri

sırasında oluşan geri esneme yok edilemez, toplu bükme işlemlerinde makine kapasitelerine göre tek kademede veya daha fazla kademede bükme işlemleri uygulanarak kalıcı şekil değişimi sağlanmakta ve bu sebeple bu yöntem diğerlerine göre daha yavaştır [12-14].
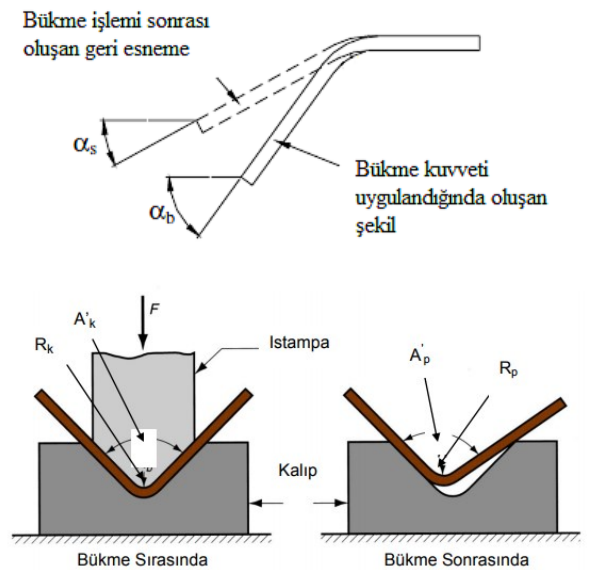

Şekil 3. Geri esnemenin şematik görüntüsü [6]

Bükme ile şekillendirme proseslerinde, akma dayanımlarının aşıldığı ancak çekme dayanımının aşılmadığı, dayanım sınırları içerisinde şekillendirilmesi için gerilme dayanımlarının gözlemlenmesi gerekmektedir. Plastik bölgede işlem yapıldığ 1 için malzeme esnekliğinin bir kısmı korunmakta bu sebeple geri esneme olayı ile meydana gelmektedir $[15,16]$. İstenilen ölçülerde bükülmüş profillerin elde edilmesi için gerilmeşekil değişimi dağılımlarının kontrol edilmesi gerekmektedir. Sonlu elemanlar metodu gibi sayısal yöntemlerle malzemelerin maksimum dayanımlarını gerçeğe yakın aralıklarda tespit etmek mümkündür. Ayrıca bu yöntemlerle çarpılma oluşumları, artık gerilme miktarı ve malzeme özellikleri gibi parametreler hakkında detaylı bilgi aktarımı sağlamakta, ayrıca sonlu elemanlar yöntemi birçok yap1 malzemesinin karakteristiği için öngörü sağlamaktadır [17].

Hudovernik ve arkadaşlarının [18] yapmış oldukları çalışmada; bükme parametrelerinden eğilme kuvveti ve momenti için sayısal modelin geçerliliğinin sağlamasını yapmışlardır. Ayrıca yükleme ve boşaltma koşullarında gerilim-gerinim durumlarının daha ileri incelemelerini gerçekleştirmişlerdir.

Vatter ve Plettice [19] yaptıkları çalışmada; üç boyutlu geometrilerin üretimi için işlem davranışlarını incelemişlerdir. Makinenin kinematiği, sürtünmesi ve rijitliği gibi bütün ilgili faktörleri dikkate alan sonlu elemanlar modeli geliştirmişlerdir. Ortaya çıkan sarmal yapıların şekil üzerindeki etkisini araştıran bir varyant simülasyon gerçekleştirmişlerdir.

Yang ve Shima [20] gerçekleştirdikleri deneyde; $\mathrm{U}$ şekilli kesite sahip iş parçasının deformasyonunu üç toplu bir bükme işlemine göre simüle etmişlerdir. İş parçasının özelliklerine bağlı olarak eğrilik ve eğilme momentinin dağılımını silindirlerin yer değişimi-dönüşüne göre hesaplamışlardır. Silindirlerin pozisyonu ve iş parçasının son eğimi arasındaki eğimi elde etmişlerdir. Deney gerçekleştirilmiş ve simülasyonun doğruluğu onaylanmıştır.

He ve arkadaşları [21] gerçekleştirdikleri inceleme çalışmasında; boru bükme prosesinin hafif ürün oluşumu için anahtar üretim teknolojilerinden biri haline geldiğini belirtmişlerdir. Bükme karakteristikleri ve çoklu kusurların analizi yoluyla, boru bükümündeki yaygın problemleri keşfetme konusundaki ilerlemeler, iç kemerdeki buruşmazlık dengesizliği, dış kemerdeki duvar incelmesi (çatlama), yayılma olayı, kesit deformasyonu, şekillendirme limiti ve prosesi hakkında bilgileri özetlemişlerdir.

Feng ve Champliaud [22] çalışmalarında; silindirik rulo bükme sırasında yanal silindirin pozisyonunun tahmin edilmesi ile ilgili gerekli kabulleri yaparak hem deney hem de sonlu elemanlar metodu vasitasıyla modelleyerek simülasyonunu gerçekleştirmişlerdir. Deney ve simülasyon sonucunun yüksek oranda birbiri ile örtüştüğünü belirtmişlerdir.

Ghiotti ve arkadaşları [23] yapmış oldukları çalışmada, üç toplu bükme süreci boyunca bükülmüş geometrinin doğru ve gerçek zamanlı ölçümüne izin veren atalet ölçüm tekniklerine dayanan yeni bir hat üzeri yaklaşım sunulmaktadır. 
Doğrulama deneyleri yanı sıra ölçüm doğruluğunun değerlendirilmesi de sunulmaktadır.

Hermes ve arkadaşları [24] yaptıkları çalışmada; profillerin 3 boyutlu bükülmesi için yeni bir yöntem göstermişlerdir. $\mathrm{Bu}$ sayede çok uzun simetrik ve asimetrik profiller yüzeyde hasar olmaksızın üç boyutlu olarak bükülebilir ve asimetrik profillerin istenmeyen torsiyonunun benzer bir dengeleme momenti ile önlenebileceğini vurgulamışlardır.

Simonetto ve arkadaşları [25] yapmış oldukları çalışmada; üç toplu bükme makinesinde işlem sırasında borunun bölümlerinin kararsızlığına bağlı kusurları tespit etmek için dinamik analiz tekniklerinin uygunluğunu kanıtlamayı amaçlamışlardır. Yaklaşımlarını faklı endüstriyel işlem koşullarına uygulamış ve sonuçları karşılaştırmış, tartışmışlardır. Önerdikleri yaklaşımın boruda görülen buruşukluğun tespiti için umut verici olduğunu belirtmişlerdir. Ayrıca proses parametrelerinin gerçek zamanlı ayarlanması için doğru geri bildirim verebildiğini bildirmişlerdir.

\subsection{Malzeme}

Kimyasal kompozisyonu belirlenmiş olan kütük malzemeler, maden ve tünelcilik sektöründe kullanılacak olan Toussaint-Heintzmann profillerinin elde edilmesi amaciyla sicak haddeleme süreçlerinin de kullanılacaktır. Maden ve tünelcilik profillerinin bükme prosesi tasarımında kullanılacak olan TH34 profiller referans alınmış olup, ilgili profile ait görsel Şekil 4'te profile ait kesit özellikleri ise Çizelge 1'de verilmiştir.
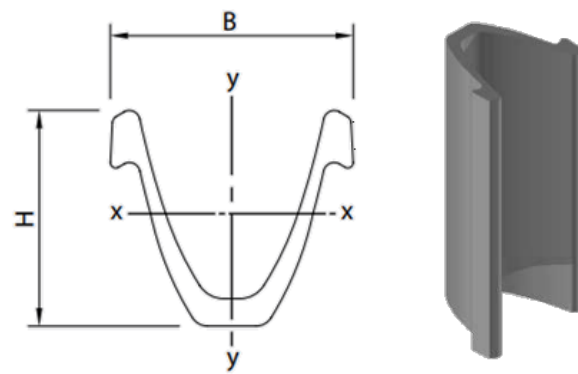

Şekil 4. TH34 Profil ve profil kesiti
Cizelge 1. TH34 profile ait kesit özellikleri

\begin{tabular}{|c|c|c|c|c|c|c|}
\hline \multirow{2}{*}{$\begin{array}{c}\text { Profil } \\
\text { Cinsi }\end{array}$} & $\mathrm{B}$ & $\mathrm{H}$ & $\mathrm{I}_{\mathrm{x}}$ & $\mathrm{I}_{\mathrm{y}}$ & $\mathrm{W}_{\mathrm{x}}$ & $\mathrm{W}_{\mathrm{y}}$ \\
\cline { 2 - 7 } & $\mathrm{mm}$ & $\mathrm{mm}$ & $\mathrm{cm}^{4}$ & $\mathrm{~cm}^{4}$ & $\mathrm{~cm}^{3}$ & $\mathrm{~cm}^{3}$ \\
\hline TH34 & 171 & 136,5 & 870 & 1.182 & 122 & 138 \\
\hline
\end{tabular}

Maden ve tünelcilik sektöründe tahkimat elemanı olarak kullanılan profillerin bükülmesi ve tasarımlarda istenilen geometriye getirilmesi aşamalarında yararlanılan bükme makinesi ile bükme prosesi tasarımları süreçlerinde kullanılan $31 \mathrm{Mn} 4$ ve S480W malzemelerine ait mekanik özellikler Çizelge 2'de verilmiştir.

Çizelge 2.31Mn4 ve S480W malzemelerine ait mekanik özellikler

\begin{tabular}{|l|c|c|}
\hline Malzeme & $31 \mathrm{Mn} 4$ & S480W \\
\hline Akma Mukavemeti (MPa) & 350 & 480 \\
\hline Çekme Mukavemeti (MPa) & 550 & 650 \\
\hline \% Uzama & 18 & 17 \\
\hline
\end{tabular}

\subsection{Yöntem}

Üç ve dört toplu bükme prosesleri metal şekillendirme sektörü, enerji mühendisliği yapıları, inşaat sektörü, maden ve tünelcilik sektörlerinde kullanılmaktadır [26-29]. Kalıpta bükme, germe bükme gibi uygulamalar, metal bükme işlemlerinde sıklıkla kullanılmaktaydı. Ancak konvansiyonel yöntemlerin kullanımları sebebiyle oluşan geri esnemenin engellenmesinde meydana gelen güçlükler, bükme işlemi sırasında oluşan yüksek malzeme fireleri ve bu sebeple oluşan yüksek üretim maliyeti, proses sonunda şekillendirmeden kalan düzlemsel yüzeylerin geniş olması gibi sorunların engellenmesi ve daha dar toleranslarda tek pasoda veya birden fazla pasoda şekillendirme işlemlerinin gerçekleştirilmesi amaciyla üç ve 4 toplu bükme işlemleri uygulanmaya başlanmıştır [30]. Dört toplu profil bükme prosesinde, bükme işlemlerinin sonrasında profilin uç kısımlarında düzlemsel olarak kalan bölgelerin daha az oranda bulunması ve dar tolerans aralıklarında işlemlerin gerçekleştirilmesinden dolayı; dört toplu profil bükme proseslerinin üç toplu bükme prosesinden daha fazla avantaj sağladığg ve daha üstün özellik içerdiği görülmektedir [30,31]. 


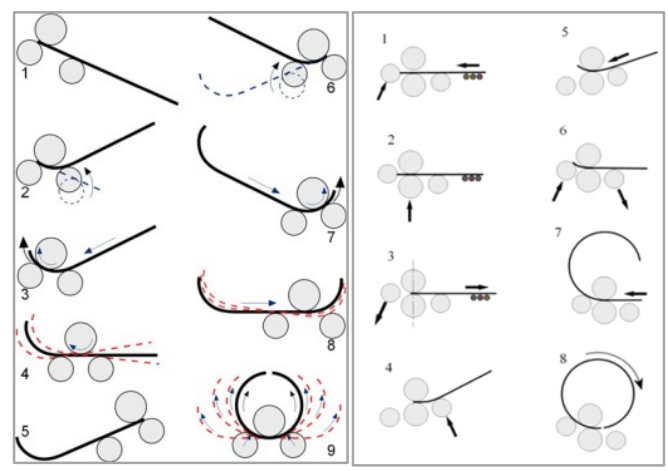

(a)

(b)

Şekil 5. (a) 3 Toplu profil bükme prosesi ve (b) 4 toplu profil bükme prosesi [32]

Üç veya daha fazla bükme vals topları profil bükme işlemlerinde kullanılmakta olup; alt topun konumu sahip, alt ve üst top dikey düzlemde eksenleri çakışık olarak çalışmaktadır (Şekil 6). Üst toplar ise y ekseni boyunca hareketlidir. Böylece deformasyon uygulanacak olan profil alt ve üst vals topları profili mesnetlenirken, yan vals topları bükme yarıçapı ölçülerinde bükme işleminin gerçekleşmesi amacıyla konum değiştirmekte ve vals toplarının dönme hareketi ile profilin itilerek bükme işlemi gerçekleşmektedir $[13,30]$.

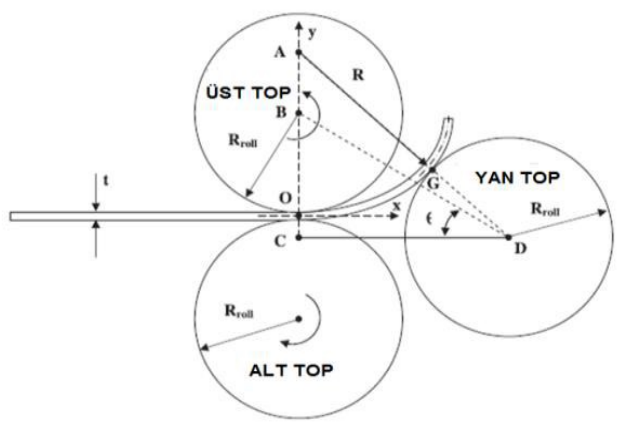

Şekil 6. 3 toplu bükme prosesi şematik görünüm [30]

Mikroalaşımlı çelik hammaddeye sahip olan maden ve tünelcilik sektöründe kullanılan profillerin şekillendirilebilirlik özelliklerinin inceleneceği sonlu elamanlar metodu temelli simülasyon faaliyetleri boyunca simufact.forming yazılımı vasıtasıyla elde edilen gerilme-şekil değiştirme eğrilerine göre en verimli bükme prosesi tasarlanmıştır (Şekil 7). Tasarlanan bükme prosesine ilişkin vals toplarına etkiyen kuvvet, tork gereksinimleri elde edilerek gerçek uygulamalarda makinenin kapasitesine uygunluğu belirlenmiştir.

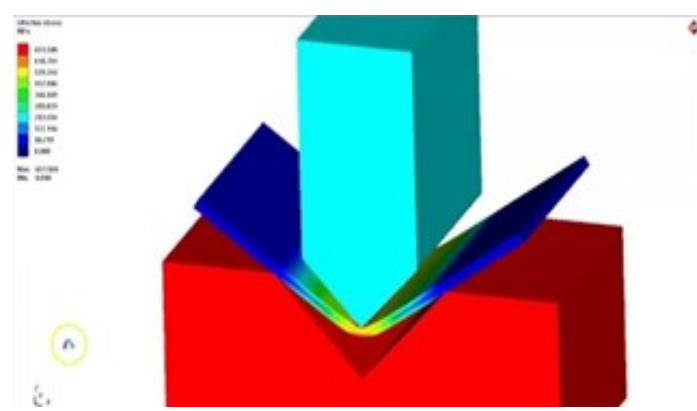

Şekil 7. Simufact forming yazılımı ile yapılmış olan örnek V bükme prosesi

Sonlu elamanlar metodu temelli simülasyon faaliyetleri kapsamında yapılan bükme simülasyonlarından elde edilen çıktılar neticesinde en verimli bükme prosesine ait parametrelerin kullanılması ile dört toplu bükme makinesinde prototip üretim uygulamaları gerçekleştirilmiştir (Şekil 8).
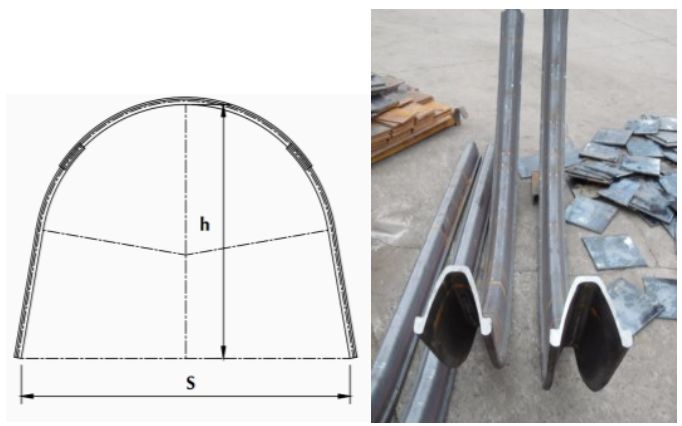

Şekil 8. Bükme makinesi tasarımı

Prototip bükme uygulaması sonrasında elde edilen bükülmüş profillere ait geri esneme miktarının tespiti; bükme prosesi öncesinde referans alınan bükme radyüs ölçülerine göre tasarlanan mastar vasıtası ile kontrol edilmiştir. Ayrıca soğuk deformasyon aşamasında malzemede hasarın meydana gelip gelmediğinin belirlenmesi amacı ile bükülmüş malzemeye sıv1 penetrant testi uygulanarak çatlak kontrolü yapılmıştır (Şekil 9). 


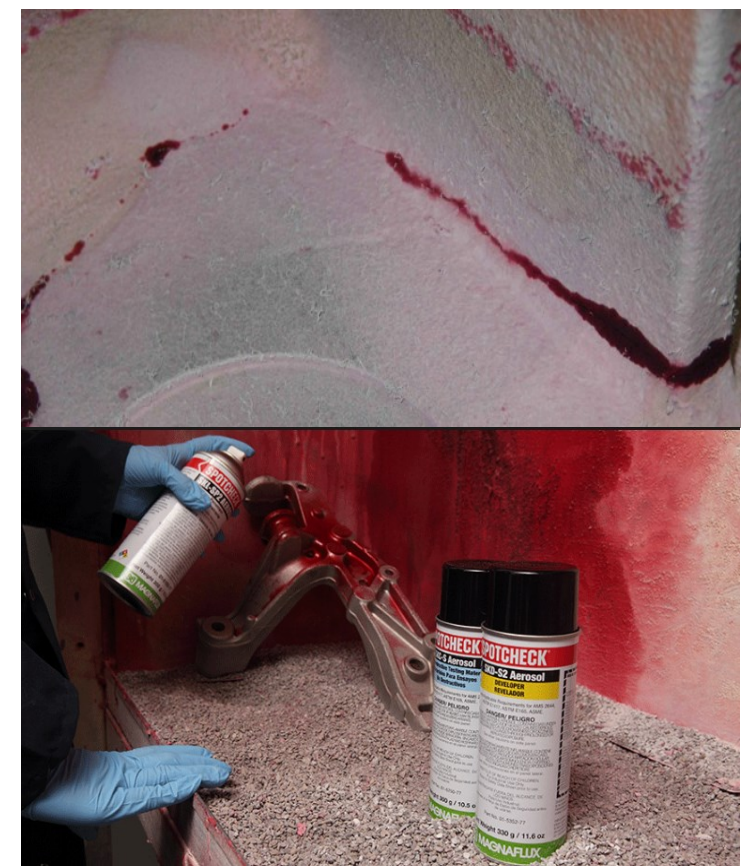

Şekil 9. Sıvı penetrant testi örneği

\section{DENEYSEL ÇALIȘMALAR}

Maden ve tünelcilik sektöründe kullanılan TH34 profillerin, belirtilen avantajlarda dahilinde, dört toplu bükme makinesinin kullanımının referans alınması ile tasarım faaliyetleri kapsamında, profil bazında bükme makinesi tasarımı gerçekleştirilmiş ve akabinde sonlu elemanlar metodu temelli çalışan simufact.forming yazılımı vasıtası ile simülasyon faaliyetleri tamamlanmıştır. Simülasyon faaliyetleri, dört toplu bükme makinesinin iki farklı prototipe göre düzenlenmesi ile gerçekleştirilmiştir. Birincisinde, yan topların avare çalışmasının sağlanması ile profile eş zamanlı bükme kuvveti uygulanmıștır. İkincisinde ise, tüm topların tahrikli olarak çalışması ile yan topların biri profile bükme kavis yarıçapı ölçüsünde kuvvet uygulayacak, diğeri üst ölü noktada durması ile bükme prosesi boyunca destek işlevi görecektir. Bükme prosesi için profile ait büküm ölçüleri Şekil 10'da verilen ölçüler referans alınarak, simülasyon faaliyetleri belirlenen ölçülere göre yapılmıştır.

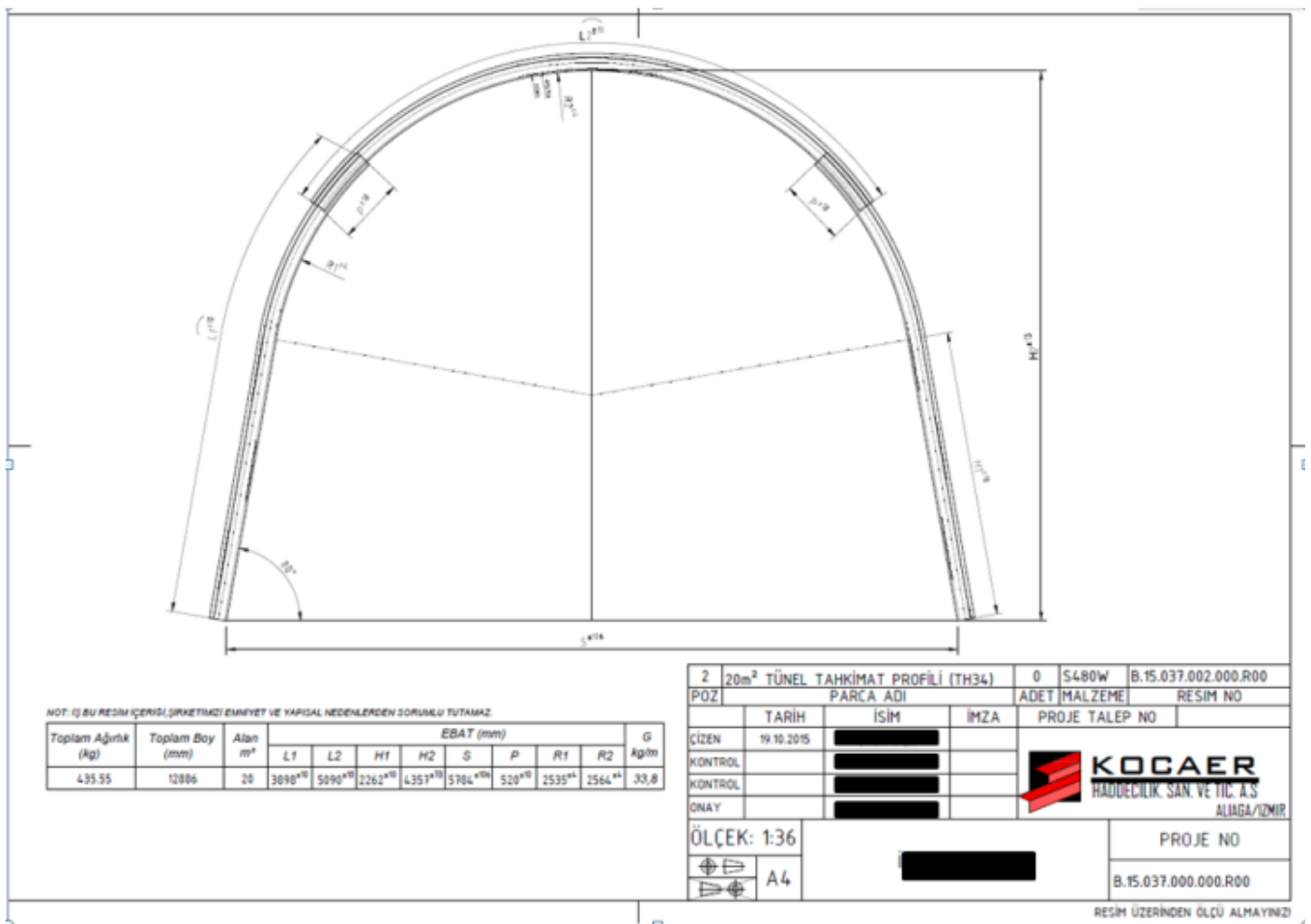

Şekil 10. Referans alınan TH34 tahkimat 
Maden ve Tünelcilik Sektöründe Kullanılan Sicak Haddelenmiş TH34 Profilin Bükme Prosesine İlişkin Simülasyon Destekli Tasarımı, Prototip Üretimi ve Tahribatsız Muayene Yöntemi ile Analizleri

Simülasyon faaliyetleri süresinde kullanılacak olan profilin kesitine uygun olarak tasarlanan bükme topları ve mekanik özellikleri daha yüksek olan S480W malzemeli TH34 profil ele alınarak bükme simülasyon faaliyetleri kurgulanmıştır. Bükme toplarının dönüş hızları $7 \mathrm{~m} / \mathrm{dk}$ 'dır (Şekil 11 ve 12).

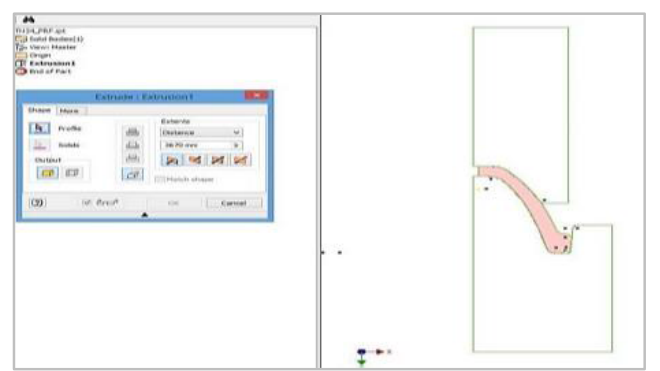

(a)

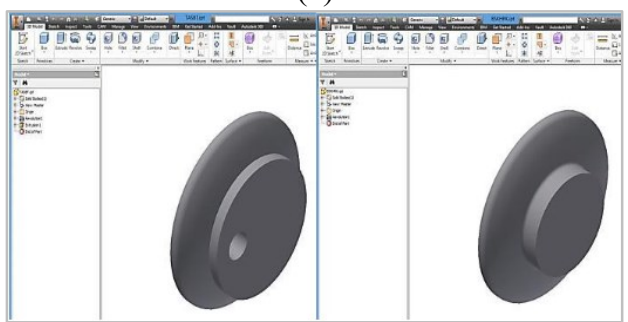

(b)

Şekil 11. (a) Bükme topu tasarımı (b) Tasarımı tamamlanan bükme topları

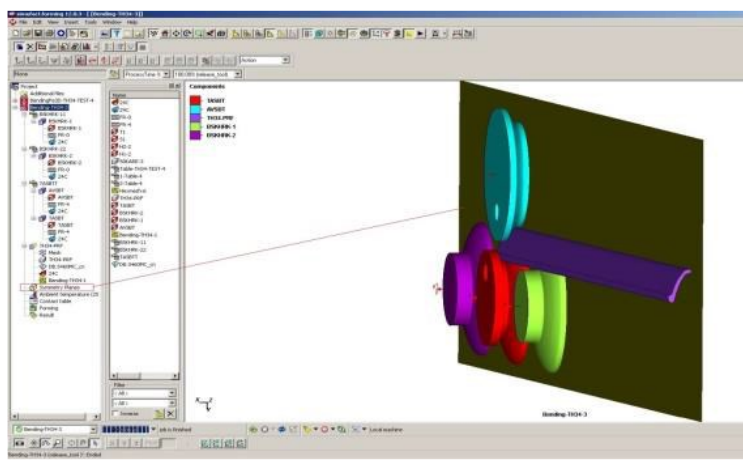

Şekil 12. Dört toplu bükme makinesine ait proses tasarımı

Simülasyon çalışmaları iki aşama olarak gerçekleştirilmiştir. İlk aşama 1. Prototipe ait sistem kurgusudur. $\mathrm{Bu}$ aşamada, yan toplar avare çalışırken, alt ve üst toplar tahrikli çalışacağ 1 varsayılmıştır. Belirtilen varsayım ile profil bükme esnasında yan toplar profile baskı yapacak şekilde tasarlanmıştır ve söz konusu varsayıma ait simülasyon faaliyetleri gerçekleştirilmiştir. 1 . Aşama sonunda elde edilen simülasyon faaliyetleri çıktıları irdelendiğinde, sitemi tahrik eden elemanların moment ihtiyaçlarının yüksek olduğu tespit edilmiştir. $\mathrm{Bu}$ sebeple simülasyon çalışmalarının ikinci aşaması olan 2. prototipe ait sistemin analizine geçilmiştir. İkinci aşamada, tüm topların tahrikli olarak çalışacağı varsayılmıştır. Belirtilen varsayıma göre, profilin bükülmesi esnasında, yan toplardan biri profili eğecek, diğeri ise üst ölü noktada duracak bu sebeple herhangi bir eğme işlemi uygulamayacak şekilde kurgulanmıştır. İkinci aşamaya ait simülasyon faaliyetlerinin gerçekleştirilmiştir (Şekil 13).

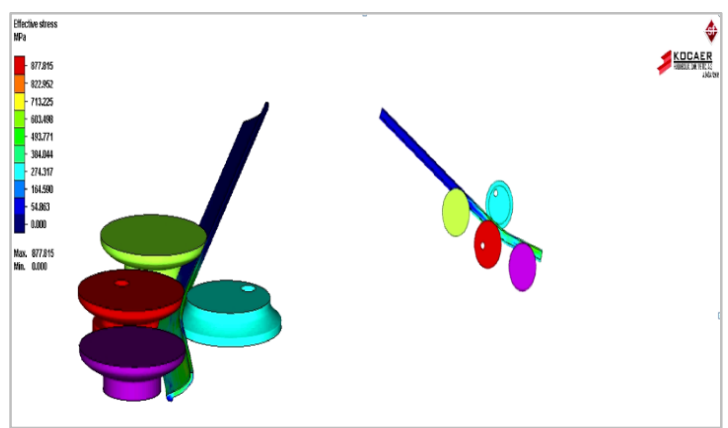

Şekil 13. Simülasyon çalışmalarının ikinci aşamasını oluşturan 2. Prototipe ait simülasyon kurgusu

Tasarım ve simülasyon faaliyetlerinde elde edilen çıktılardan yararlanılarak bükme prosesine ait prototip üretimler yapılmıştır (Şekil 14).

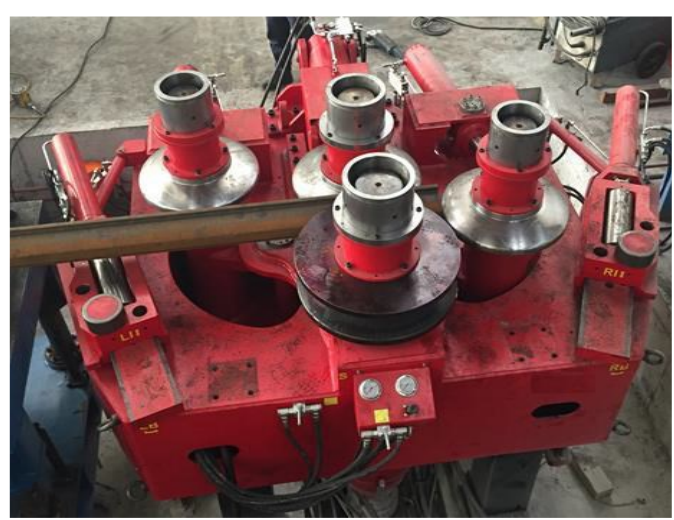

Şekil 14. Bükme prosesi uygulaması 
Maden ve tünel inşa sektöründe bükülmüş profillerin kullanılması ile oluşturulan tahkimatların servis ömürlerini belirlemede en büyük etken olan profil yüzeylerinde kılcal çatlakların tespit edilerek düşük kaliteli ürünlerin elde edilmesinin engellenmesi tahribatsız muayene yöntemleri ile bükme prosesi sonunda gerçekleştirilmektedir. Galeri ölçülerine göre büküm işlemi gerçekleştirilen profillerin yüzeylerinde meydana gelmesi muhtemel süreksizlikler, yapısal bozukluklar ve yüzeyin durumu gibi kaliteyi etkileyen parametrelerin belirlenmesi amac1 ile öncelikli olarak gözle kontrol gerçekleştirilmiş, gözle görülmesi mümkün olmayan kılcal çatlakların belirlenebilmesi amacı ile penetrant sıvı tahribatsız muayene yöntemi ile kontrol gerçekleştirilmiştir (Şekil 15).

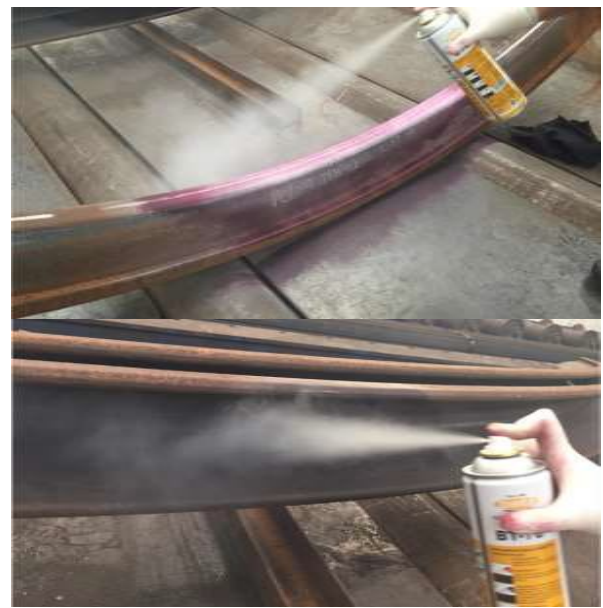

Şekil 15. Bükülmüş TH34 profillerin iç ve diş yüzeylerine sıvı penetrant yöntemlerinin uygulaması

\section{SONUÇLAR}

Simülasyon faaliyetlerini oluşturan, yan topların avare çalıştırılarak bükme prosesinin gerçekleştirildiği ilk aşama olan 1. prototip ve yan topların tahrikli olarak çalışması ile bükme prosesinin gerçekleştirildiği ikinci aşama olan 2. prototip sistemlere ait simülasyon çalışmaları tamamlanarak, elde edilen simülasyon faaliyetleri sonuç ve çıktılarını oluşturan profil bükme proseslerinde toplara etkiyen kuvvetler ile dönme momenti gereksinimleri Şekil 16-24'te verilmiştir.

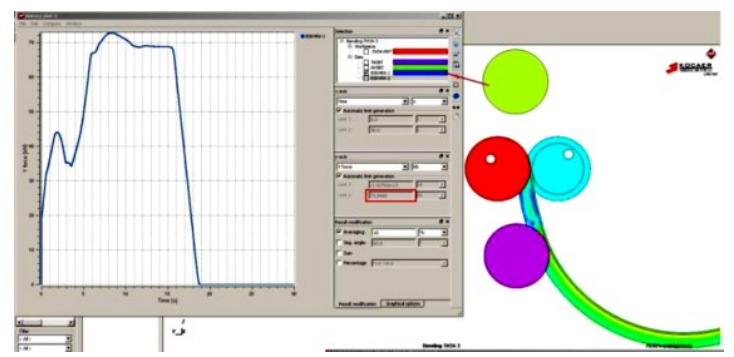

(a)

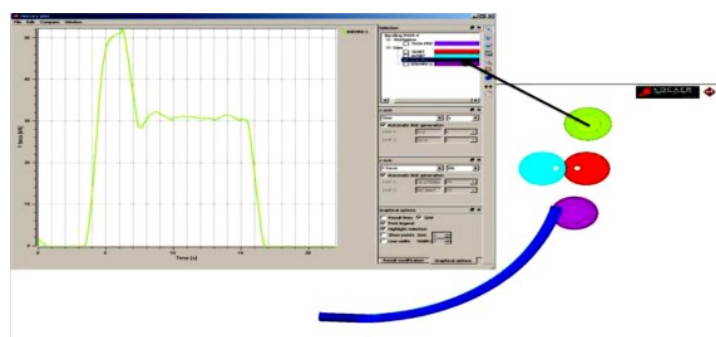

(b)

Şekil 16. (a) 1. prototipe ait sağ yan bükme topuna etki eden kuvvet dağılım grafiği (b) 2. prototipe ait să̆ yan bükme topuna etki eden kuvvet dağılım grafiğgi

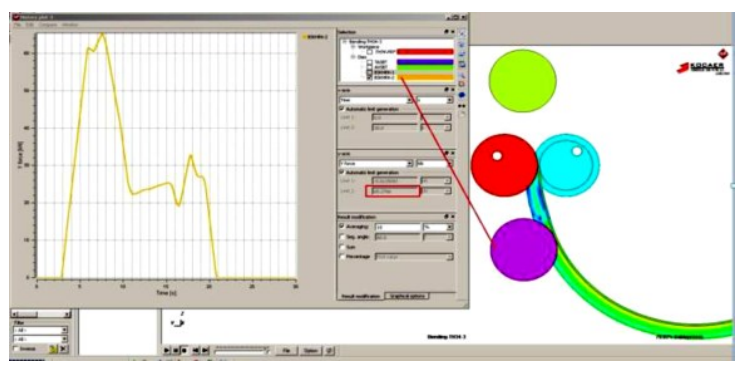

(a)

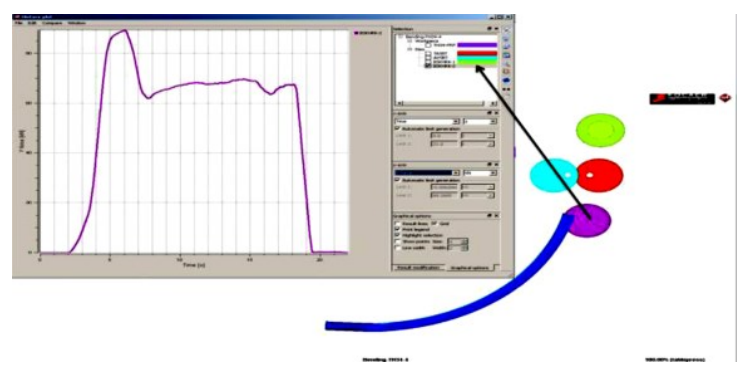

(b)

Şekil 17. (a) 1. prototipe ait sol yan bükme topuna etki eden kuvvet dağılım grafiği (b) 2. prototipe ait sol yan bükme topuna etki eden kuvvet dağılım grafiği 
Maden ve Tünelcilik Sektöründe Kullanılan Sicak Haddelenmiş TH34 Profilin Bükme Prosesine İlişkin Simülasyon Destekli Tasarımı, Prototip Üretimi ve Tahribatsı Muayene Yöntemi ile Analizleri

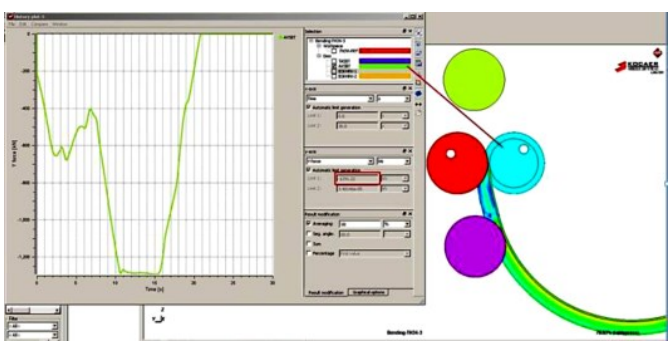

(a)

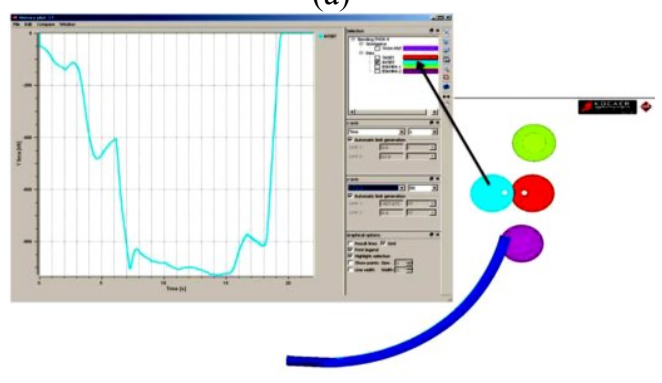

(b)

Şekil 18. (a) 1. prototipe ait alt bükme topuna etki eden kuvvet dağılım grafiğgi (b) 2. prototipe ait alt bükme topuna etki eden kuvvet dağılım grafiği

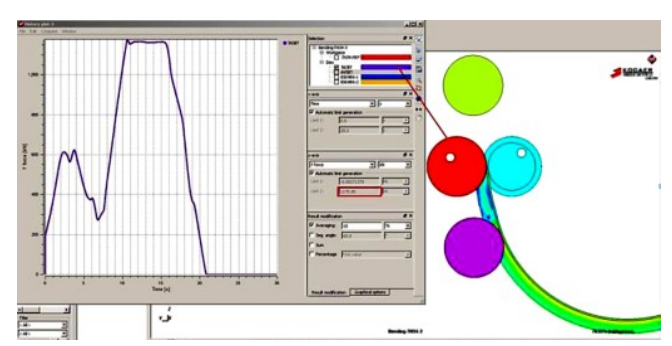

(a)

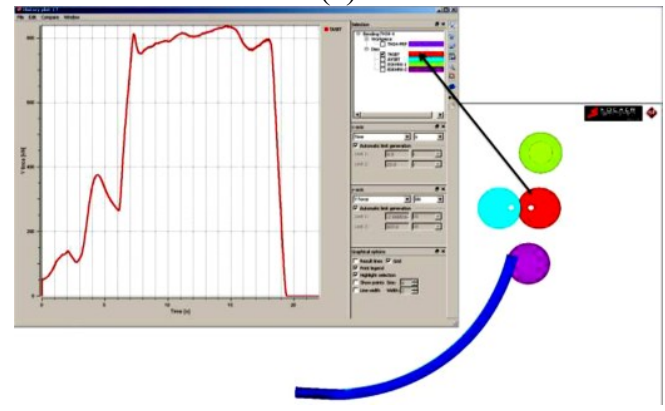

(b)

Şekil 19. (a) 1. prototipe ait üst bükme topuna etki eden kuvvet dağılım grafiğgi (b) 2. prototipe ait üst bükme topuna etki eden kuvvet dağılım grafiği

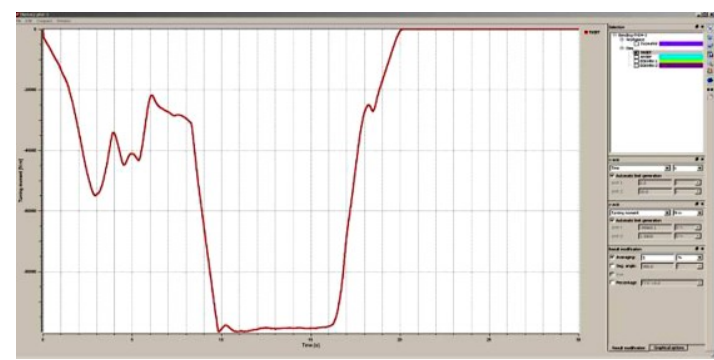

(a)

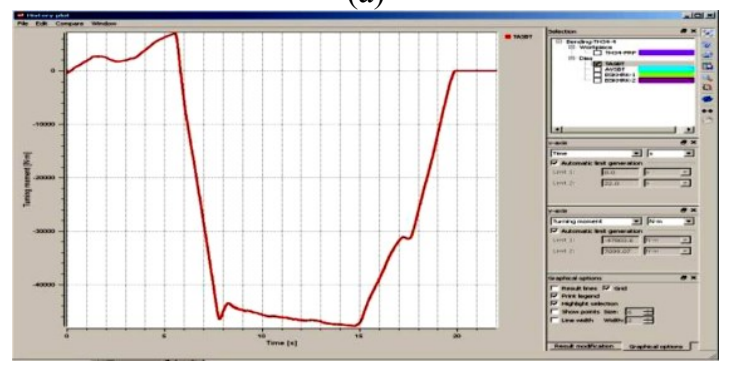

(b)

Şekil 20. (a) 1. prototip tasarımda kullanılan üst bükme topuna ait moment grafiği (b) 2. prototip tasarımda kullanılan üst bükme topuna ait moment grafiği

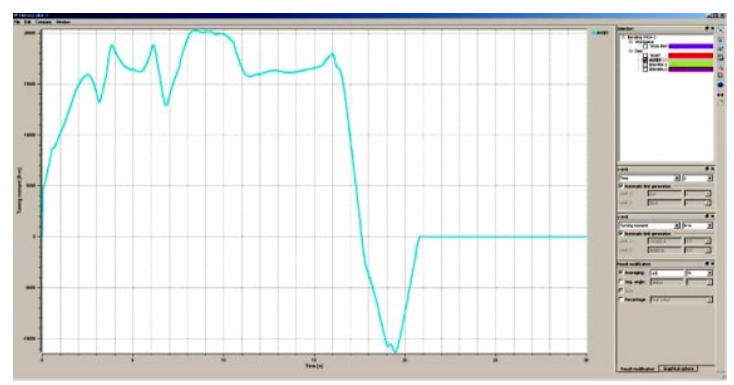

(a)

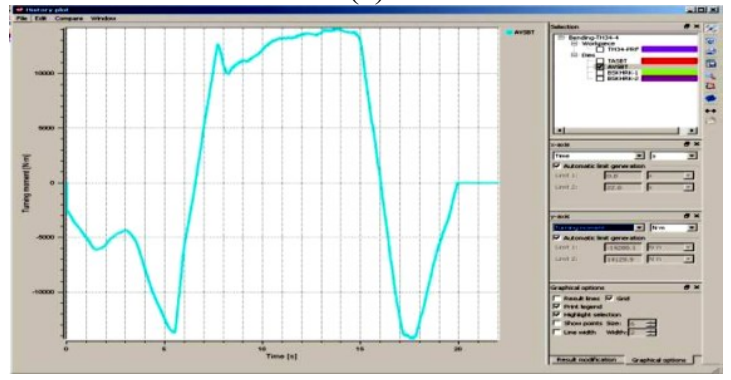

(b)

Şekil 21. (a) 1. prototip tasarımda kullanılan alt bükme topuna ait moment grafiği (b) 2. prototip tasarımda kullanılan alt bükme topuna ait moment grafiği 


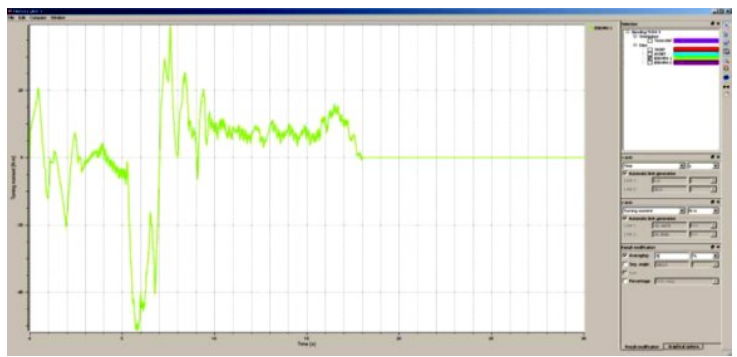

(a)

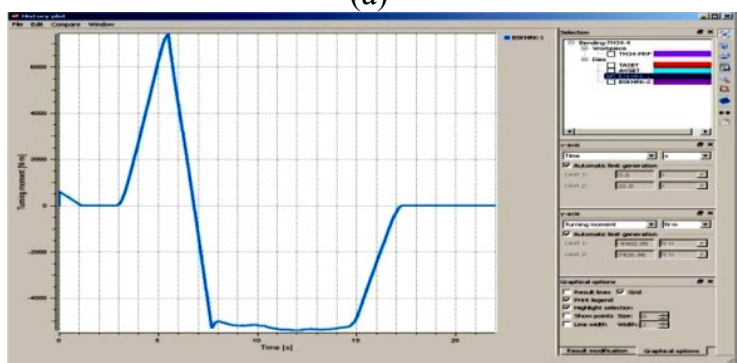

(b)

Şekil 22. (a) 1. prototip tasarımda kullanılan sağ yan bükme topuna ait moment grafiği (b) 2. prototip tasarımda kullanılan sağ yan bükme topuna ait moment grafiği

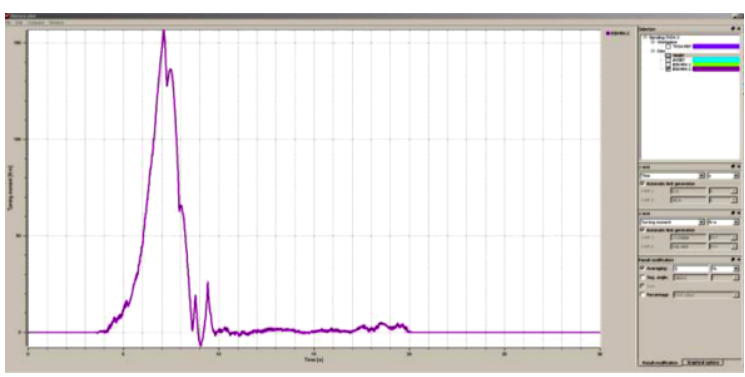

(a)

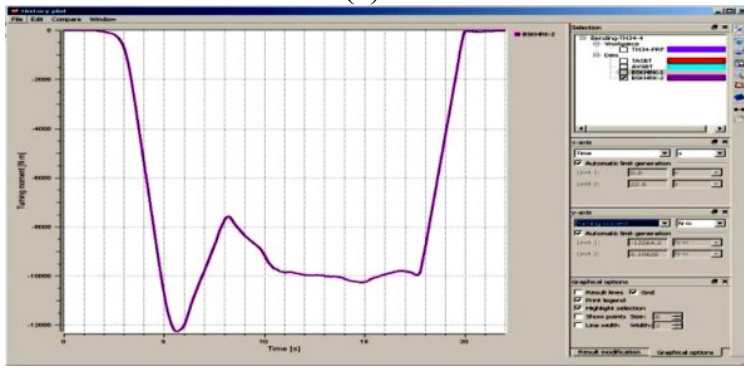

(b)

Şekil 23. (a) 1. prototip tasarımda kullanılan sol yan bükme topuna ait moment grafiği (b) 2. prototip tasarımda kullanılan sol yan bükme topuna ait moment grafiği

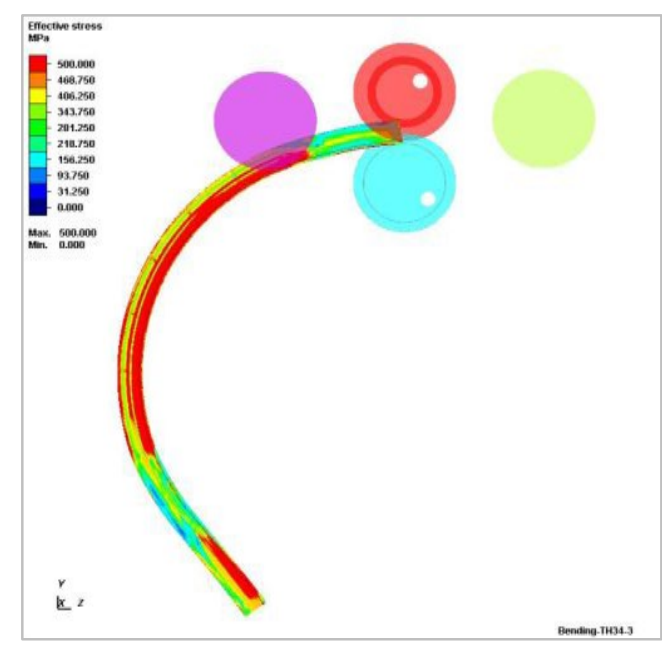

(a)

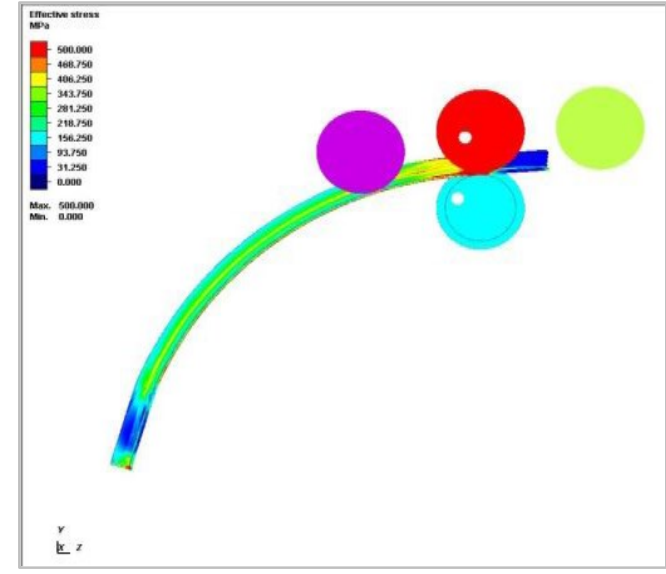

(b)

Şekil 24. (a) 1. prototip tasarım kullanılarak gerçekleştirilen bükme prosesi sonunda malzemedeki gerilme dağılımları (b) 2. prototip tasarım kullanılarak gerçekleştirilen bükme prosesi sonunda malzemedeki gerilme dağılımları

Çizelge 3. Prototip tasarımlara ait simülasyon çıtıları

\begin{tabular}{|c|c|c|c|c|c|}
\hline \multicolumn{2}{|c|}{ Bileșen Adı } & Sağ Top & Sol Top & Alt Top & Üst Top \\
\hline \multirow{2}{*}{$\begin{array}{c}\text { Dönme } \\
\text { Momenti } \\
\text { Nm }\end{array}$} & $\begin{array}{c}\text { Prototip } \\
1\end{array}$ & 102,8 & 313,0 & 40615,6 & 199938,2 \\
\hline & $\begin{array}{c}\text { Prototip } \\
2\end{array}$ & 148 & 24528,4 & 28560,2 & 95607,2 \\
\hline \multirow{2}{*}{$\begin{array}{c}\text { Etkiyen } \\
\text { Kuvvet } \\
\text { kN }\end{array}$} & $\begin{array}{c}\text { Prototip } \\
1\end{array}$ & 145,6 & 30,6 & 2582,4 & 0,2 \\
\hline & $\begin{array}{c}\text { Prototip } \\
2\end{array}$ & 104,2 & 178,6 & 1855,4 & 1674,0 \\
\hline
\end{tabular}


Prototip bükme prosesi sonucunda elde edilen profile uygulanan sivi penetrant tahribatsiz muayene sonuçları Şekil 25 'te verilmiştir.

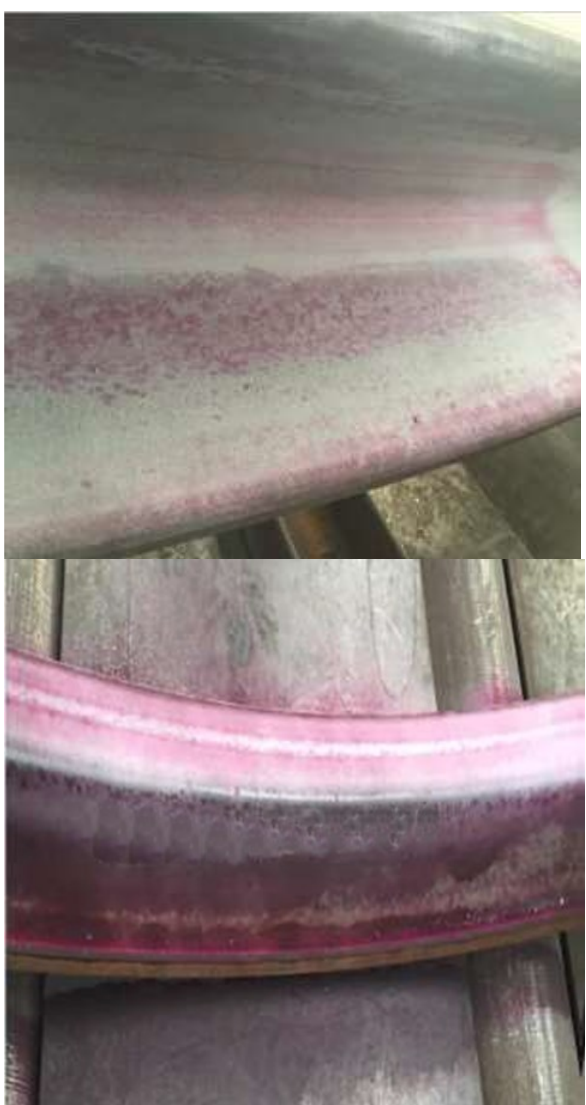

Şekil 25. Bükülmüş TH34 Profilin iç ve diş yüzeyinin tahribatsı muayene sonundaki yüzey görüntüsü

\section{GENEL SONUÇLAR VE TARTIŞMA}

Maden ve tünelcilik sektöründe kullanılacak olan TH34 profillere farklı tahrik mekanizmaların göre uygulanan simülasyon faaliyetlerinin çıtıları irdelendiğinde aşağıda belirtilen sonuçlar elde edilmiştir.

- 1. ve 2. prototip tasarımlar uygulanan bükme simülasyonları sirasında TH34 profillerde meydana gelen eşdeğer gerilmeler incelenmiştir. Her iki simülasyon sonuçlarının incelenmesi sırasında, meydana gelen eşdeğer gerilmeler malzemelerin akma dayanımlarından yüksek olduğu ve plastik şekil verme işlemlerinin maksimum çekme dayanımından düşük gerilmelerde olduğu belirlenmiştir. Böylece, malzemeye plastik bölge sinırları içerisinde gerilme uygulandığında, her iki prototip bükme makinesinde de elde edilen sonuçlara göre malzemelerde hasarın oluşmayacağı görülmektedir.

- Simülasyon faaliyetlerini olușturan iki farklı aşama incelenmiş olup, birinci aşama olan yan topların avare şekilde çalıştığı ve her iki yan topun malzemeye prototip bükme sırasında kuvvet ve bask1 uyguladığı 1. prototip tasarımda üst bükme topuna $2350,2 \mathrm{kN}$, alt bükme topuna $2582,4 \mathrm{kN}$, sağ yan bükme topuna $145,6 \mathrm{kN}$, sol yan bükme topuna $130,6 \mathrm{kN}$ değerinde kuvvetlerinin etkidiği belirlenmiştir. Yan topların tahrikli olduğu ve yan topun birinin bükme işlemi sırasında malzemeye kuvvet ve bask1 uyguladığı diğerinin ise üst ölü bölgede durması ile söz konusu malzemeye kuvvet uygulamadıği 2. prototip tasarımda ise, üst bükme topuna $1674 \mathrm{kN}$, alt bükme topuna $1855,4 \mathrm{kN}$, sağ yan bükme topuna $104,2 \mathrm{kN}$, sol yan bükme topuna 178,6 $\mathrm{kN}$ kuvvet etkidiği belirlenmiștir. 2. prototipte yan topların bükme işlemi için kuvvet uygulamaması durumunda ise, alt ve üst toplara etki eden kuvvetin sirasiyla \%28,2 ve \%28,8 oranında düşüş gösterdiği tespit edilmiştir. Böylece, bükme prosesi için gerekli olan kuvvetin ortalama \%28,5 oranında azaldığ 1 ve eş ark ölçüsüne sahip profilin belirlenen ortalama kuvvet aralığında bükülebileceği sonucuna varılmıştır.

- Simülasyon faaliyetlerini oluşturan iki farklı aşama incelenmiş olup, her iki aşamaya ait aynı ark ölçüsünde bükme işlemlerinin uygulanabilmesi amacıyla 
gerekli olan dönme momenti ihtiyaçları belirlenmiştir. $\mathrm{Bu}$ sebep ile, 1. prototip için tahrik mekanizmalarının ihtiyacı olan döndürme momentleri, alt bükme topunun 40615,6 Nm, üst bükme topunun 199938,2 Nm, sağ bükme topunun 102,8 Nm, sol bükme topunun $313 \mathrm{Nm}$ dir. 2. prototip için tahrik mekanizmalarının ihtiyacı olan döndürme momentleri ise, alt bükme topunun 28560,2 Nm, üst bükme topunun 95607,2 Nm, sağ bükme topunun $14853,8 \mathrm{Nm}$, sol bükme topunun 24528,4 Nm olup, yan bükme toplarının kontrollü bükme işlemlerini gerçekleştiriğgi tespit edilmiştir.. Elde edilen sonuçlara göre 2. prototip tasarım için sağ ve sol bükme toplarının moment ihtiyaçlarının arttığı tespit edilmiş olup, üst bükme topunda $\% 47$ ve alt bükme topunda $\% 30$ azalış gerçekleştiği görülmüştür. Böylece, 2. prototip tasarımda aynı ark ölçüsünde bükme işlemlerinin yapılabilmesi için daha düşük güce sahip motor kullanılarak enerji sarfiyatının sağlanması ve bu nedenle daha tasarruflu ve enerji verimliliği daha yüksek olacağı tespit edilmiştir. Ayrıca daha homojen soğuk deformasyonun, yan bükme toplarının kontrollü bükme işlemlerine katkı sağlaması sebebiyle 2 . Prototip tasarımda gerçekleşebileceği anlaşılmıştır.

Simülasyon faaliyetleri sonucunda elde edilen çıktılar göz önünde bulundurularak gerçekleştirilen prototip bükme prosesi sonrasında elde edilen TH34 profillere uygulanan sivi penetrant tahribatsiz muayeneye ait aşağıda belirtilen sonuçlar elde edilmiştir.

- Maden ve tünelcilik sektöründe bükülmüş olan profillerin kullanılması için tahkimat servis ömrünün belirlenmesinde en önemli etkenlerden biri olan profil yüzeylerinde kılcal çatlakların tespit edilerek düşük kaliteli ürünlerin elde edilmesinin engellenmesi amaciyla prototip bükme işlemleri sonucunda elde edilen TH34 profillerin iç ve diş yüzeyleri ilk olarak görsel olarak incelenmiş akabinde, tahribatsız muayene yöntemlerinden sivi penetrant testi uygulanarak profilin iç ve dış yüzeyleri gözlemlenmiştir. Yapılan görsel muayene sonucunda, gözle görülecek boyutta hataların olmadığ 1 tespit edilmiştir. Galeri ölçülerine ve açıklıklarına göre bükülmüş olan profillerin büküm bölgelerinin içi ve dış yüzeylerinde gözle görülemeyecek boyuttaki hataların, süreksizliklerin ve yapısal bozuklukların tespit edilmesi amaciyla yapilan sivi penetrant sonucunda her iki yüzeyde de herhangi bir hata ile karşılaşılmamıştır. Bu sebeple, ürün kalitesini etkileyen bir sebep olmadığından en verimli bükme prosesinin gerçekleştiği anlaşılmıştır.

\section{KAYNAKLAR}

1. Doğan, İ., 2012. Tabanyolu Tahkimatı Olarak Geçme (TH) Bağ Uygulamaları ve Performans Değerlendirmeleri, Yüksek Lisans Tezi, Zonguldak Karaelmas Üniversitesi Fen Bilimleri Enstitüsü Maden Mühendisliği Anabilim Dal, Zonguldak.

2. Özer, S.C., 2011. Tünel Kazılarında Optimum Çelik Boru Kemer Boyutunun Nümerik Modelleme ile Tayini, Dokuz Eylül Üniversitesi Fen Bilimleri Enstitüsü Maden Mühendisliği Bölümü Maden İşletme Anabilim Dalı Yüksek Lisans Tezi, İzmir.

3. Ünlü, K., 2010. Bir Demiryolu Tünelinin Tahkimat Analizleri, Selçuk Üniversitesi Fen Bilimleri Enstitüsü Maden Mühendisliği Anabilim Dalı Yüksek Lisans Tezi, Konya.

4. Kömürlü, E., Kesimal, A., Çolak, Ü., 2014. Poliüre Türü Püskürtülen İnce Kaplamaların Kaya Saplamaları Performansları Üzerindeki Etkileri, Madencilik TMMOB Maden Mühendisleri Odası Dergisi, 53(3-4), 13-18.

5. Toptaş, C., 2015. Yassı Çelik Haddelemede Kullanılan Sicak Şerit Haddehane Hadde Merdanelerinin Aşınma Parametrelerinin Optimizasyonu ile Servis Ömürlerinin Uzatılması, İstanbul Üniversitesi Fen Bilimleri 
Maden ve Tünelcilik Sektöründe Kullanılan Sicak Haddelenmiş TH34 Profilin Bükme Prosesine İlişkin Simülasyon Destekli Tasarımı, Prototip Üretimi ve Tahribatsız Muayene Yöntemi ile Analizleri

Enstitüsü Makine Mühendisliği Anabilim Dalı Konstrüksiyon Programı Yüksek Lisans Tezi, İstanbul.

6. Witthaus, H.P.R., Breedlove, J., 2009. Development in Steel Roadway Support- A Track Recod. The $27^{\text {th }}$ International Conference on Ground Control in Mining, Morgantown, West Virginia 2009 Strata Products (USA) Inc., 358-365.

7. Panthi, S.K., Ramakrishnan, N., Ahmed, M., Singh, S.S., Goel, M.D., 2010. Finite Element Analysis od Sheet Metal Bending Process to Predict the Springback. Journal of Materials and Design 31, 657-662.

8. Öztürk, F., Toros, S., Kılı., S., 2009. Tensile and Sprindback Behaviour of DP600 Advanted High Strength Steel at Warm Temperatures, Journal of Iron and Steel Research, 16(6), 41-46.

9. Gomes, C., Onipede, O., Lovell, M., 2005. Investigation of Springback in High Strength Anisotropic Stells, Journal of Material Processing Technology 159, 91-98.

10. Sitar, M., Kosel, F., Brojan, M., 2015. Numerical and Experimental Analysis of Elastic-plastic Pure Bending and Springback of Beams of Asymmetric Crosssections, International Journal of Mechanical Sciences, 77-85.

11. Tekaslan, Ö., Gerger, N., Şeker, U., 2008. V Bükme Kalıplarında Bakır Sac Malzemelerin Geri Esneme Miktarlarının Tespiti. Gazi Üniv. Müh. Mim. Fak. Dergisi, 23, 231-238.

12. Uzun, İ., Erişkin, Y., 1997. Sac Metal Kalıpçılığ, MEB, 253-286, Ankara.

13. Semiatin, S.M., 1988. Forming and Forging Volume 14-9 ${ }^{\text {th }}$ Edition Metals Handbook, ASM International, 1499-1451.

14. Erişkin, Y., 1986. Uygulamalı Sac Metal Kalıp Konstrüksiyonu, Gazi Üniversitesi Eğitim Fakültesi, 73-126, Ankara.

15. Tekaslan, Ö., Gerger, N., Şeker, U., 2008. V Bükme Kalıplarında Bakır Sac Malzemelerin Geri Esneme Miktarlarının Tespiti, Gazi Üniversitesi Mühendislik Mimarlık Fakültesi Dergisi, 23(1), 231-238.

16. Tan, Z., Persson, B., Magnusson, C., 1992. An Empiric Model for Controlling Springback in V-Die Bending of Sheet Metals, Journal of
Materials Processing Technology, 34(1-4), 449-455.

17. Spoorenberg, R.C., Snijder, H.H., Hoenderkamp, J.C.D., 2012. Mechanical Properties of Roller Bent Wide Flange Sections-Part 1: Experimental Investigations, Journal of Constructional Steel Research 68, 51-62.

18. Hudovernik, M., Staupendahl, D., Gharbi, M., Hermes, M., Tekkaya, A.E., Kuzman, K., Slabe J.M., 2013. 3D Numerical Analysis of 2D Profile Bending with the Torque Superposed Spatial Bending Method, Journal of Mechanical Engineering 59(3), 139-147.

19. Vatter, P.H., Plettke, R., 2013. Process Model for the Design of Bent 3-dimensional Freeform Geometries for the Three-roll-pushbending Process, Forty Sixth CIRP Conference on Manufacturing Systems 2013, Procedia CIRP 7, 240-245.

20. Yang, M., Shima, S., 1988. Simulation of Pyramid Type Three-Roll Bending Process, Printed in Great Britain, Int. J. Mech. Sci., 30(12), 877-886.

21.He, Y., Heng, L., Zhiyong, Z., Mei, Z., Jing, L., Guangjun, L., 2012. Advances and Trends on Tube Bending Forming Technologies, Chinese Journal of Aeronautics 25, 1-12.

22. Feng, Z., Champliaud, H., 2011. Modeling and Simulation of Asymmetrical Three-roll Bending Process, Simulation Modelling Practice and Theory 19, 1913-1917.

23. Ghiotti, A., Simonetto, E., Bruschi, S., Bariani, P.F., 2017. Springback Measurement in Three Roll Push Bending Process of Hollow Structural Sections, CIRP AnnalsManufacturing Technology, CIRP-1677, 4.

24. Hermes, M., Chatti, S., Weinrich, A., Tekkaya, A.E., 2008. Three-Dimensional Bending of Profiles with Stress Superposition, International Journal of Material Forming Suppl 1,133-136.

25. Simonetto, E., Ghiotti, A., Bruschi, S., 2017. Dynamic Detection of Tubes Wrinkling in Three Roll Push Bending, Procedia Engineering 207, 2316-2321.

26. Spoorenberg, R.C., Snijder, H.H., Hoenderkamp, J.C.D., 2011. Finite Element Simulations of Residual Stresses in Roller Bent 
Wide Flange Sections, Journal of Constructional Steel Research 67, 39-50.

27. Spoorenberg, R.C., Snijder, H.H., Hoenderkamp, J.C.D., 2010. Experimental Investigation of Residual Stresses in Roller Bent Wide Flange Steel Sections, Journal of Constructional Steel Research 66, 737-747.

28. Hudovernik, M., Staupendahl, D., Gharbi, M., Hermes, M., Tekkaya, E., Kuzman, K., Slabe, J.M., 2013. 3D Numerical Analysis of 2D Profile Bending with the Torque Superposed Spatial Bending Method, Journal of Mechanical Engineering 59(3), 139-147.

29. Chatti, S., Hermes, M., Tekkaya, A.E., Klenier, M., 2010. The New TSS Bending Process: 3D Bending of Profiles with Arbitrary Crosssections, CIRP Annals-Manufacturing Technology 59, 315-318

30. Feng, Z., Champliaud, H., 2011. Modeling and Simulation of Asymmetrical Three-roll Bending Process. Simulation Modelling Practice Theory, 19, 1913-1917.

31. Hua, M., Baines, K., Cole, I.M., 1999. Continuous Four-roll Plate Bending: a Production Process for the Manufacture of Single Seamed Tubes of Large and Medium Diameters., International Journal of Machine Tools \& Manufacture 39, 905-935.

32. Url:https://www.thefabricator.com/article/ bending/plate-rolls-keep-rolling-heavier-plate (Erişim Tarihi: 28.06.2018) 
